\title{
Preliminary notes on floristic composition and structural profiles of lowland deciduous forest fragments: A case study in Lampang Campus of Thammasat University, Northern Thailand
}

\author{
Janejaree Inuthai \\ Department of Biotechnology, Faculty of Science and Technology, Thammasat University, Lampang Campus, \\ Hang Chat, Lampang 52190 Thailand
}

e-mail: j.inuthai@gmail.com

\begin{abstract}
The present study provides preliminary information on floristic composition of lowland deciduous forest fragments in Thammasat University, Lampang Campus, Lampang Province, Northern Thailand. A total of 110 vascular plant species belonging to 43 families and 89 genera were collected and identified. The most common species were Dipterocarpus obtusifolius, Dipterocarpus tuberculatus, Cratoxylum cochinchinense, Diospyros ehretioides, Garcinia nigrolineata, and Anacardium occidentale. The structural profiles of straight stems, sparsely distributed trees, and open crowns with 3 layers were constructed. In addition, the lowland deciduous forest fragments on the campus are considered the young to the intermediate-staged secondary forests in the present study.
\end{abstract}

KEYWORDS: deciduous forest, forest structural profile, Lampang, Northern Thailand, secondary forest

\section{INTRODUCTION}

There are 2 types of forests in Thailand - the deciduous and evergreen forests. The deciduous forests are mainly found in the northern, north-eastern, and central part of Thailand. In northern Thailand, deciduous forests are classified into 3 categories: mixeddeciduous forest, dry dipterocarp forest, and pinedeciduous dipterocarp forest [1].

Currently, the original deciduous vegetation throughout northern Thailand is decreasing at an alarming rate due to the threats posed by human activities such as opening for crops, fire, and unsustainable logging practices that were rampant and had been in practice for over 100 years $[2,3]$. Furthermore, the urban center and agricultural development expansion in the plain areas that cause forest fragmentation are rising. Consequently, all these activities have left behind only remnant patches of forest in the lowland vegetation in most places. Such a trend exacerbates the situation as it alters the plant habitat and removes the native species of ecological importance.

Although the deciduous forest is important at the local and regional level, and ample study focusing on it has not been conducted so far compared to the study related to tropical rain forest [4]. Only a few studies on plant species diversity and vegetation in a deciduous forest in northern Thailand were conducted at Doi Khun Tan National Park [5], Chae Son National Park [2], and Doi Suthep-Pui National Park [6]. Furthermore, the previous studies conducted on the mountain ranges where vegetation's structural profiles have not been recorded. Hence, there is a dearth of knowledge and literature on the floristic composition and vegetation profile of lowland deciduous forest in northern Thailand.

The profile diagrams are crucial in describing certain general features of the forest structures that are not well represented and explained by the photographs and quantitative data [7]. Understanding plant diversity, composition, and structural profile is imperative for forest ecological study and provides essential information for long-term monitoring of environmental change, forest management, and wildlife conservation $[4,6,8,9]$.

The vegetation study on the remnant and fewer disturbed areas is a good way to fill the gaps of knowledge before that forest information is permanently destroyed. The information gathered from the study will act like many small jigsaw puzzles that help to complete the whole picture. Hence, the current study investigates the floristic composition and structural profiles of lowland deciduous forest in Thammasat University, Lampang Campus, Lampang Province, where the fragments of this forest type are still maintained.

\section{MATERIALS AND METHODS}

\section{Study sites: Location}

The present study was carried out at Thammasat University, Lampang Campus, Hang Chat District, Lampang Province, Thailand ( $\left.18^{\circ} 19^{\prime} 1.6^{\prime \prime} \mathrm{N} 99^{\circ} 23^{\prime} 52.2^{\prime \prime} \mathrm{E}\right)$ (Fig. S1). It is around $30 \mathrm{~km}$ from Doi Khun Tan National Park (area: $255 \mathrm{~km}^{2}$, elevation: 325- 
$1363 \mathrm{~m} \mathrm{msl}$ ), contiguous in the north to Chae Son National Park (area: $768 \mathrm{~km}^{2}$, elevation: 300$2031 \mathrm{~m} \mathrm{msl}$ ). The campus covers around $0.58 \mathrm{~km}^{2}$ with scattered deciduous forest. The 2 study sites, Site I and Site II, encompass $17404.86 \mathrm{~m}^{2}$ and $15729.62 \mathrm{~m}^{2}$, respectively. The study sites were selected based on ocular inspection, the largest fragment, and less disturbed areas of deciduous forest in the University (Fig. S2).

The topology is flat at an elevation of 257-267 msl with loamy sand soil bearing a $\mathrm{pH}$ ranging from 5.67.5. The climate is strongly seasonal, experiencing the hot and dry season from February to April, followed by the rainy season from May to October, and the cool and dry season from November to January. The annual mean temperature is about $27^{\circ} \mathrm{C}$ with the maximum of $42^{\circ} \mathrm{C}$ in April and minimum of $7.5^{\circ} \mathrm{C}$ in December. The annual rainfall is about $864.3-1186.8 \mathrm{~mm}$, the amount of rainfall during the rainy season is 771.5$988.2 \mathrm{~mm}$, and amount of rainfall in the dry season is $86.2-198.6 \mathrm{~mm}$. The highest rainfall occurs during July to August. The average relative humidity is about $74.33 \%$ [10].

\section{Data collection}

\section{Floristic study}

All the vascular plant specimens with reproductive organs were collected twice a month from November 2018 to October 2019 and once a month from September to December 2020. The voucher specimens were prepared following the procedure described by Bridson and Forman [11]. The abundance of species in each study site was estimated and recorded based on the percentage cover explained by Kent and Coker [12]. The percentage covers were given the average scores as: $5=$ most abundant (76-100\%), $4=$ more abundant (51-75\%), $3=$ common (26-50\%), $2=$ few $(6-25 \%)$, $1=$ rare $(1-5 \%)$, and $0=$ absent. The habits of all the species were noted.

The index of similarity determines the interspecific association between the species of plant communities. Sorensen's test was used to measure the species similarities and differences among the study site I and II based on their presence or absence and associations. Sorensen's species similarity index (SI) was calculated according to Nath et al [13]: SI $(\%)=100 \times 2 c /(a+$ $b)$, where SI (similarity index) is a percentage of the total number of taxa in both sites with possible values ranging from 0 (none in common) to 100 (all taxa shared); $c$ is the number of shared taxa in both sites; $a$ and $b$ are the numbers of taxa in study sites I and II.

\section{Laboratory study}

The plant specimens were identified using the Flora of Thailand, Flora of China, and other available taxonomic literature including the appropriate taxonomic

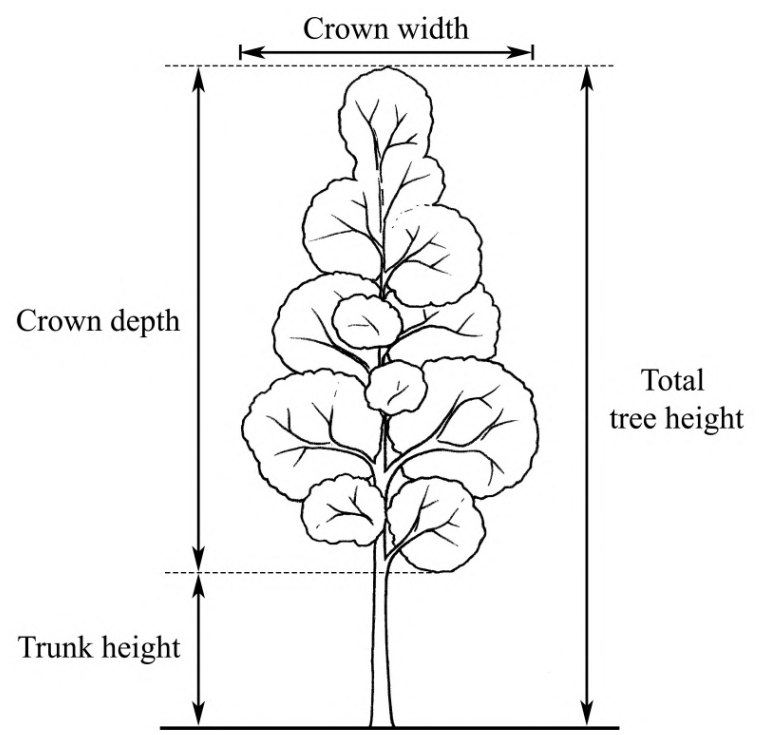

Fig. 1 Schematic diagram indicating the measurement of total tree height, trunk height, crown width, and crown depth.

websites. Scientific names and author abbreviations were assigned based on International Plant Names Index, The Plant List, and Tem Smitinand's Thai Plant Names, Revised Edition [14]. The voucher specimens have been deposited at the Biotechnology Laboratory of Thammasat University, Lampang Campus, Lampang Province, Thailand.

\section{Vegetation study}

For the construction of profile diagram, a belt-transect of $55 \times 10 \mathrm{~m}$ was laid on the forest floor through the center of the forest within each study site. All vascular plant species were carefully observed by walking along the transects. At the same time, a rough sketch diagram of each plant species' characteristic and position including crown shape was drawn, and other details were recorded in the field book. The tree height, crown width, and crown depth were initially estimated. Crown width was considered by projecting the edges of the crown to ground level and measuring the length along one axis from edge to edge through the crown center. Crown depth was defined as the depth of the crown, calculated as the difference between total tree height and the trunk height defined as the height from the ground to the first living branch or the lowest foliage (Fig. 1). Still, they were confirmed later with the help of the Smart Measure application [15], where telemeter measures the distance and height of the target object using trigonometry. Then, the final profile diagram of representative forest in each study site was illustrated and constructed to scale. 


\section{RESULTS}

\section{Species richness and composition}

The study recorded 110 species of vascular plants belonging to 43 families and 89 genera (Table S1), and the most diverse family in the study area was Fabaceae with 24 species. The other commonly occurring families include Malvaceae ( 8 species), followed by Apocynaceae and Convolvulaceae with 6 species each and Asteraceae and Lamiaceae with 5 species. The genera with the highest number of species were Sida with 4 species. The most common tree species of the forest in both study sites were Dipterocarpus obtusifolius, Dipterocarpus tuberculatus, Cratoxylum cochinchinense, and Diospyros ehretioides including Garcinia nigrolineata that was found only in study site I, and Anacardium occidentale that was found only in study site II. The tree species contributed $14.54 \%$ to the overall plant species in the study areas, while the shrub, herb, climber, and terrestrial orchid had contributed $28.18 \%, 32.73 \%$, $23.64 \%$, and $0.91 \%$, respectively.

Of the 110 species, 89 species $(80.91 \%)$ were present in study site I, and 59 species (53.64\%) were present in study site II. Due to the niche overlap and community similarity, the similar index values for study sites I and II stand at 51.35\% (Table S1). It confirms that the vegetation of both sites belongs to a similar community because the index values were higher than $25 \%$, and it is considered high similarity by Sørensen coefficient range of $51-75 \%$ [16].

\section{Structural profiles}

The forest fragments found in study sites I and II are represented by the profile diagrams (Fig. 2 and Fig. 3). The profile diagram shows emergent trees with straight stems sparsely distributed and bears open crown covers in 3 layers. Dipterocarpaceae dominates the top canopy above $12 \mathrm{~m}$ high, where individual trees can be distinguished from a long distance. The middle canopy is around 6-12 $\mathrm{m}$ high. The shrub canopy is less than $6 \mathrm{~m}$ high. The forest floor is generally composed of tree saplings, herbaceous plants, and climbers.

In study site I, the crown cover is less open than the study site II (Fig. 2). The top canopy is dominated by Dipterocarpus obtusifolius, D. tuberculatus that bears narrowly crowns, and Sindora siamensis var. siamensis. Over two-thirds of the trees in this upper stratum are deciduous, and their deciduousness is obligate, taking place with unfailing regularity every dry season. In the middle canopy, some young dipterocarps are present, but most of the trees in this layer belong to Garcinia nigrolineata, Diospyros ehretioides, and Parinari anamensis. The most frequently occurring shrub species in the shrub canopy are Cratoxylum cochinchinense, Cratoxylum formosum subsp. pruniflorum, Dillenia aurea, Dillenia obovata, Memecylon scutellatum var. scutellatum, and Strychnos nux-blanda. The commonly occurring herbaceous species are Brucea ja- vanica, Flemingia stricta, Hyptis suaveolens, Indigofera cassioides, Indigofera hirsuta, Phyllodium pulchellum, Sida spp., Triumfetta pilosa, and Urena rigida. Climbers are also abundant in the forest floor and include Centrosema pubescens, Ichnocarpus frutescens, Ipomoea pestigridis, Mikania micrantha, and Toxocarpus villosus.

In study site II, the crown cover is more open (Fig. 3). Dipterocarpus obtusifolius and D. tuberculatus are most important trees in the top canopy while Anacardium occidentale with wide-spreading crowns is predominant in the middle canopy, but Diospyros ehretioides is also well represented. The most frequently occurring shrub species in the shrub canopy are like the study site I. The dominant herbaceous species are Brucea javanica, Ellipeiopsis cherrevensis, Eurycoma longifolia, Flemingia stricta, Murdannia gigantea, Ochna integerrima, Sida cordifolia, Tephrosia vestita, Triumfetta pilosa, and Urena rigida. The dominant climbers include Aristolochia tagala, Ichnocarpus frutescens, Merremia vitifolia, and Streptocaulon juventas.

\section{DISCUSSION}

The deciduous forest in the present study can be classified as deciduous dipterocarp forest (dry dipterocarp forest) based on the floristic composition and structural profile. The forest fragments on the campus are the fewer disturbed areas; however, the floristic composition and diversity were altered due to agricultural development and the construction of the University for about 30 years. Thus, the lowland deciduous dipterocarp forest fragments in the present study can be described here as the young to the intermediatestaged secondary forest.

There are 2 National Parks in Lampang Province, in which the lowland deciduous dipterocarp forests have been preserved, viz., Doi Khun Tan National Park and Chae Son National Park. Nevertheless, the lowland vegetation at the National Parks was destroyed and changed by agriculture in several decades [5] and logging operations for over centuries [2]. Therefore, they are described here as the old-staged secondary forest by comparison with the age of forest fragments in the present study.

Although, there is no information on the size of lowland deciduous dipterocarp forests in the National Parks, it can imply that those areas are much larger than the forest fragments on the campus. So, it may be difficult to directly compare the plant species diversity of both areas. However, a comparison of the young to the intermediate-staged secondary forest and the old-staged secondary forest provides interesting data and valuable information particularly in the floristic composition and common species.

The record shows 1285 plant species among 6 vegetation types at Doi Khun Tan National Park. The floristic composition of the young to the intermediate- 


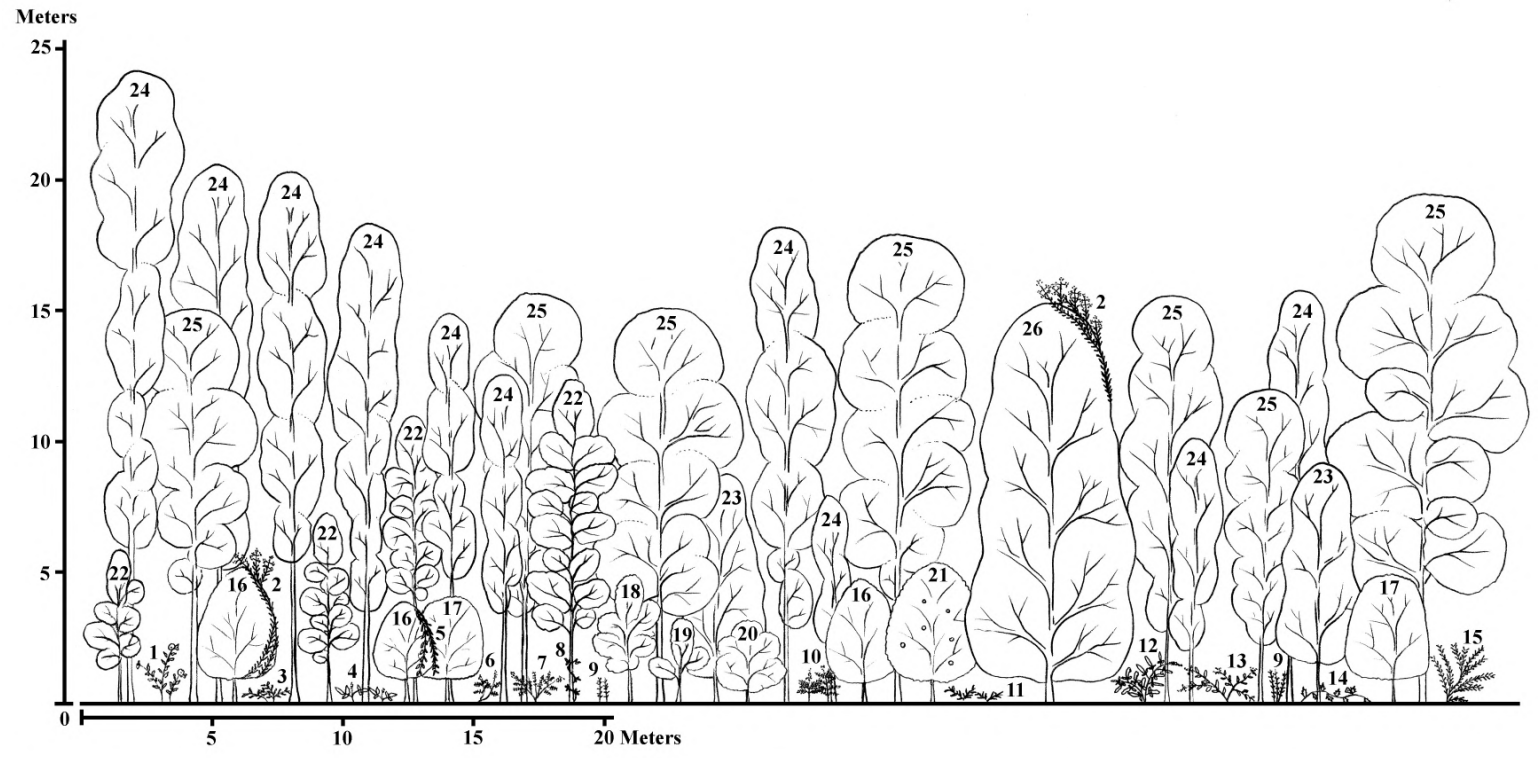

Fig. 2 The profile diagram of lowland deciduous forest fragment on the campus in the study site I: 1. Urena rigida, 2. Ichnocarpus frutescens, 3. Triumfetta pilosa, 4. Flemingia stricta, 5. Toxocarpus villosus, 6. Indigofera hirsuta, 7. Indigofera cassioides, 8. Centrosema pubescens, 9. Hyptis suaveolens, 10. Brucea javanica, 11. Sida acuta, 12. Phyllodium pulchellum, 13. Desmodium velutinum subsp. velutinum, 14. Ipomoea pes-tigridis, 15. Ziziphus oenoplia, 16. Cratoxylum cochinchinense, 17. Cratoxylum formosum subsp. pruniflorum, 18. Dillenia aurea, 19. Dillenia obovata, 20. Memecylon scutellatum var. scutellatum, 21. Strychnos nux-blanda, 22. Garcinia nigrolineata, 23. Diospyros ehretioides, 24. Dipterocarpus tuberculatus, 25. Dipterocarpus obtusifolius, and 26. Sindora siamensis var. siamensis.

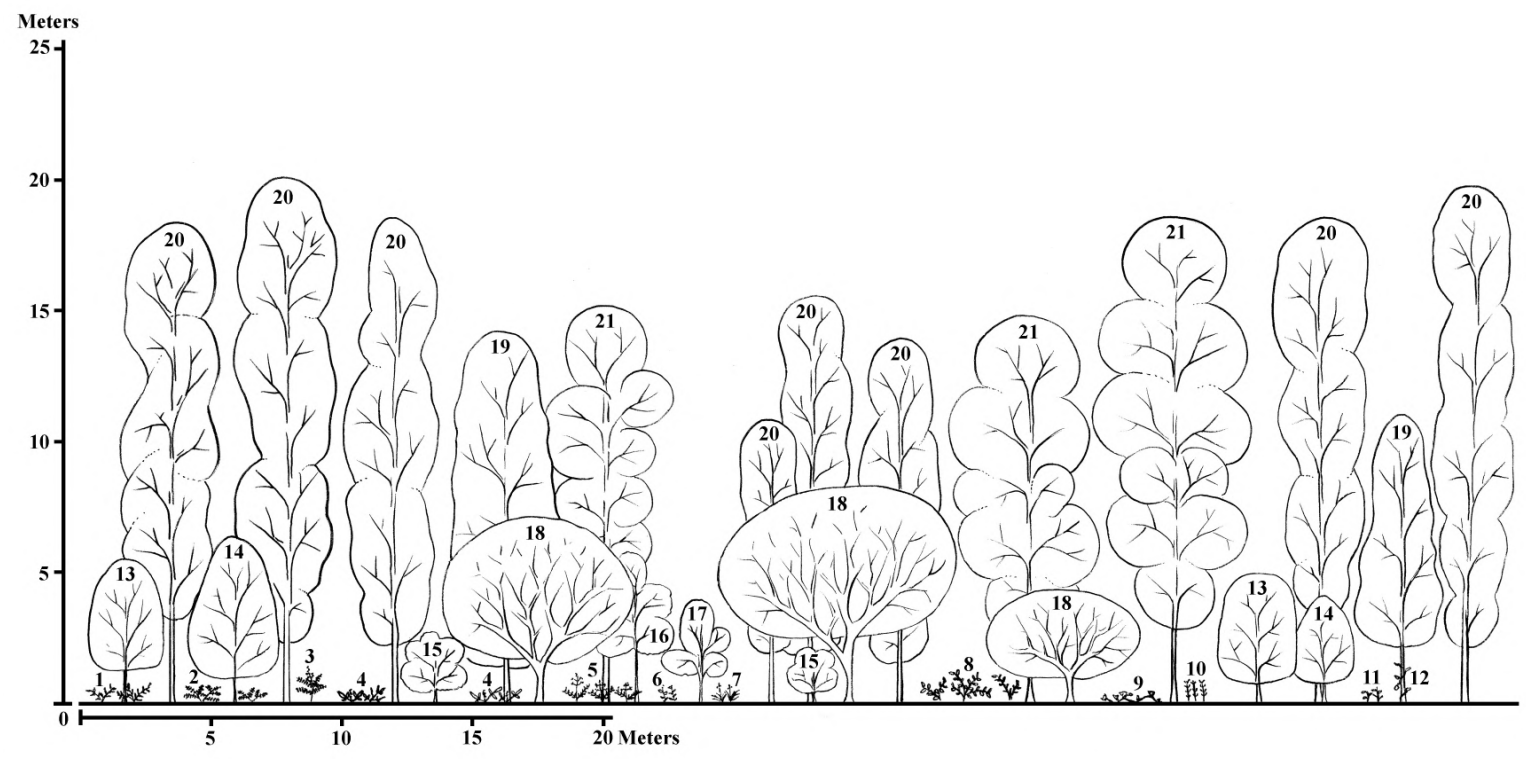

Fig. 3 The profile diagram of lowland deciduous forest fragment on the campus in the study site II: 1. Triumfetta pilosa, 2. Tephrosia vestita, 3. Brucea javanica, 4. Flemingia stricta, 5. Eurycoma longifolia, 6. Sida cordifolia, 7. Murdannia gigantea, 8. Ochna integerrima, 9. Merremia vitifolia, 10. Hyptis suaveolens, 11. Ellipeiopsis cherrevensis, 12. Aristolochia tagala, 13. Cratoxylum formosum subsp. pruniflorum, 14. Cratoxylum cochinchinense, 15. Memecylon scutellatum var. scutellatum, 16. Dillenia aurea, 17. Dillenia obovata, 18. Anacardium occidentale, 19. Diospyros ehretioides, 20. Dipterocarpus tuberculatus, and 21. Dipterocarpus obtusifolius. 
staged secondary forest on the campus shares similarity with the old-staged secondary forest of lowland vegetation at Doi Khun Tan National Park [5] as these 2 areas share common dicot weeds that include $\mathrm{Eu}$ phorbia heterophylla, Hyptis suaveolens, Ipomoea pestigridis, Lindernia crustacea var. crustacea, Merremia vitifolia, Mimosa diplotricha, Mimosa pudica, Phyllanthus urinaria, Sida rhombifolia, and Urena rigida. The family Dipterocarpaceae are dominant in the deciduous dipterocarp-oak forests at the National Park and share similarity with the present study in all aspects except in the lack of Quercus kerrii Craib var. kerrii (Fagaceae, an oak). Maxwell et al [5] mentioned that it takes much time (centuries) for oaks to develop in the devastated areas than the Dipterocarpaceae. Hence, this evidence confirms that the secondary forest fragments in the present study is much younger than in the National Park. Other plant species common between these 2 areas are Diospyros ehretioides, Ochna integerrima, Hoya kerrii, etc.

There were 1353 plant species within 11 vegetation types at Chae Son National Park [2]. The results from the present study are related to the oldstaged secondary forest of deciduous dipterocarp-oak association at Chae Son National Park [2]. As in the Dipterocarpaceae, trees are widespread and dominant in the forest although the species are different. The climbers are common in the young to the intermediatestaged secondary forest on the campus while vines, in contrast, are scarce on the old-staged secondary forest in the National Park. This high abundance of climbers is one of the distinguishing characteristics of the young secondary forests [17]. Epiphytic orchids are abundant in Chae Son National Park compared to only one terrestrial orchid species found in the present study. The ground is covered with dense herbs, particularly Zingiberaceae, in most areas after the rainy season in Chae Son National Park. In contrast, Fabaceae species is frequently found in the present study.

Even though the forest fragment on the campus might be tiny, it bears the potential to harbour many species and remains a very important area to be considered in biodiversity conservation. As Andersson [18] proposed, the small remnant habitats are important for biodiversity conservation in agricultural landscapes, and the management in a way that preserves heterogeneity may be crucial for its continued species richness. Furthermore, empirical studies suggest that habitat loss has significant, consistently negative effects on biodiversity while habitat fragmentation has much weaker effects on that [19].

As Lui et al [20] claimed, forest recovery can cause differences in the canopy structures, and the findings from secondary forests in the present study relate very well with it as the forests are found in 3 canopy layers. However, the study site I has more densely wooded and less open canopy than study site II. Based on the history of study areas, the secondary forest fragment in study site I is considered a non-burned area (without the action of fire) while the forest fragment in study site II is typically disturbed by a fire.

The results show that the most important tree component in the middle canopy of study site I is Garcinia nigrolineata though it is absent in study site II. Moreover, there is $95.83 \%$ (23 species) of Fabaceae in study site I compared to only $41.67 \%$ (10 species) in study site II. The occurrence of Clusiaceae and Fabaceae families indicates that this forest fragment is in an intermediate stage as the tree species belong to mesic forest types that will invade such forest [4]. As Ribeiro et al [21] mentioned, the germination of seeds from seed banks probably played an important role in the regeneration of herbaceous species in nonburned stands. The abundance of understory and herbaceous plants including saplings on the forest floor in this study site is likely to affect forest growth and development in a near future. It is possible that the dense canopy trees with their large leaves create a more shaded and cooler environment which may be more suitable for understory species in the later stages of succession [21]. Therefore, this study site may be in an intermediate stage of succession that may soon give way to a new stage of a dry evergreen forest if maintained without any further disturbance. On the other hand, the characteristic structure of deciduous dipterocarp forest has been maintained in study site II. It could be attributed to the disturbance caused by a fire from a railway located outside the University. According to Lamotte et al [4], the forest fire is described as the most important factor for maintaining the forest structure and species composition in deciduous dipterocarp forests. Thus, the lowland deciduous forest fragments on the campus are described here as the young to the intermediate-staged secondary forest.

The present study provides a better understanding of the floristic composition and structural profiles of lowland deciduous forest fragments (the young to the intermediate-staged secondary forest) including the overview of the floristic composition and common taxa in the young, intermediate, and old stages of secondary forests in northern Thailand.

\section{CONCLUSION}

The lowland deciduous forest fragments in Thammasat University, Lampang Campus, represent the structure of the young to the intermediate-staged secondary forest in northern Thailand. The species composition of this forest type on the campus is like the studies in the protected areas in the same province (Doi Khun Tan National Park and Chae Son National Park). The results confirm that the small fragment habitats are crucial for biodiversity conservation and suggest that the forest fragments on the campus have a value for improving the University's natural learning center. 


\section{Appendix A. Supplementary data}

Supplementary data associated with this article can be found at http://dx.doi.org/10.2306/scienceasia1513-1874. 2022.016 .

Acknowledgements: I would like to express my sincere appreciation to Dr. Naiyana Tetsana, Forest Herbarium, Department of National Parks, Wildlife and Plants Conservation, Bangkok, Thailand, for her hospitality and valuable suggestions. My sincere thanks to Mr. Tobgay, Wangbama Central School, Thimphu, Bhutan, for his support and very kind help for proofreading and English correction. Miss Visuda Keawnunchai, a scientist, Department of Biotechnology, Faculty of Science and Technology, Thammasat University, Lampang, Thailand, is thanked for providing valuable support and time for the field data collection. I sincerely appreciate the reviewers for all their valuable comments and suggestions to improve the manuscript. This study was supported by Thammasat University Research Fund, Contract No. TUFT $021 / 2563$

\section{REFERENCES}

1. Santisuk T (2006) Vegetation Types in Thailand, The Forest Herbarium, Department of National Parks, Wildlife and Plant Conservation, Bangkok.

2. Maxwell JF, Elliott S, Anusarnsunthorn V (1997) The vegetation of Jae Sawn National Park, Lampang Province, Thailand. Nat Hist Bull Siam Soc 45, 71-97.

3. Wangpakapattanawong P, Tiansawat P, Sharp A (2016) Forest restoration at the landscape level in Thailand. In: Appanah S (ed) Forest Landscape Restoration for AsiaPasific Forest, The Food and Agriculture Organization of the United Nations and RECOFTC-The Center for People and Forest, Bangkok, pp 149-166.

4. Lamotte S, Gajaseni J, Malaisse F (1998) Structure diversity in three forest types of north-eastern Thailand (Sakaerat Reserve, Pak Tong Chai). Biotechnol Agron Soc Environ 2, 192-202.

5. Maxwell JF, Elliott S, Palee P, Anusarnsunthorn V (1995) The vegetation of Doi Khuntan National Park, LamphunLampang Provinces. Nat Hist Bull Siam Soc 43, 185-205.

6. Khamyong N, Wangpakapattanawong P, Chairuangsri S, Inta A, Tiansawat $\mathrm{P}$ (2018) Tree species composition and height-diameter allometry of three forest types in northern Thailand. Chiang Mai Univ J Nat Sci 17, 289-306.

7. Richards PW (1996) The Tropical Rain Forest (An Ecological Study), 2nd edn, Cambridge University Press, Cambridge.
8. Saiful I, Latiff A (2017) Stand profile topography of a primary hill dipterocarp forest in Peninsular Malaysia. $J$ Trop For Sci 29, 137-150.

9. Tendar P, Sridith K (2021) Vegetation structure of wetlands in Eastern Himalayan Highlands of Gasa, Bhutan. ScienceAsia 47, 78-85.

10. Lampang Agromet (2018-2020) Climatological Data for the Period 2018-2020, Northern Meteorological Center, Meteorological Department. Available at: https://drive.google.com/drive/folders/1 ng5qZ6IS7Q4kzb6N4d6ofi-xZ-pnB7I.

11. Bridson D, Forman L (1998) The Herbarium Handbook, 3rd edn, Whitstable Litho Printers Ltd, London.

12. Kent M, Coker P (1992) Vegetation Description and Analysis: A Practical Approach, John Wiley \& Sons Ltd, Chichester.

13. Nath PC, Arunachalam A, Khan ML, Arunachalam K, Barbhuiya AR (2005) Vegetation analysis and tree population structure of tropical wet evergreen forests in and around Namdapha National Park, Northeast India. Biodivers Conserv 14, 2109-2135.

14. Pooma R, Suddee S (2014) Tem Smitinand's Thai Plant Names, Revised Edition 2014, The Forest Herbarium, Department of National Park, Wildlife and Plant Conservation, Bangkok.

15. Smart Tools Corporation (2020) Smart Measure (1.7.3). Available at: https://android-apk.org/kr.sira.measure/ 54975502-measure/.

16. Ratliff RD (1993) Viewpoint: trend assessment by similarity, a demonstration. J Range Manag 46, 139-141.

17. Schroeder JM, Oke DO, Onyekwelu JC, Yirdaw E (2010) Secondary forests in West Africa: a challenge and opportunity for management. In: Mery G, Katila P, Glenn G, Alfaro R, Markku K, Max L, Jari V (eds) Forests and Society-Responding to Global Drivers of Change, IUFRO World, International Union of Forest Research Organizations (IUFRO), Vienna, pp 335-354.

18. Andersson K (2010) How important are small remnant habitats for biodiversity in the agricultural landscape? MSc thesis, Stockholm Univ, Sweden.

19. Fahrig L (2003) Effects of habitat fragmentation on biodiversity. Annu Rev Ecol Evol Syst 34, 487-515.

20. Lui S, Wei X, Li D, Lu D (2017) Examining forest disturbance and recovery in the subtropical forest region of Zhejiang Province using Landsat time-series data. Remote Sens 9, ID 479.

21. Ribeiro MBN, Bruna EM, Mantovani W (2010) Influence of post-clearing treatment on the recovery of herbaceous plant communities in Amazonian secondary forests. Restor Ecol 18, 50-58. 
Appendix A. Supplementary data

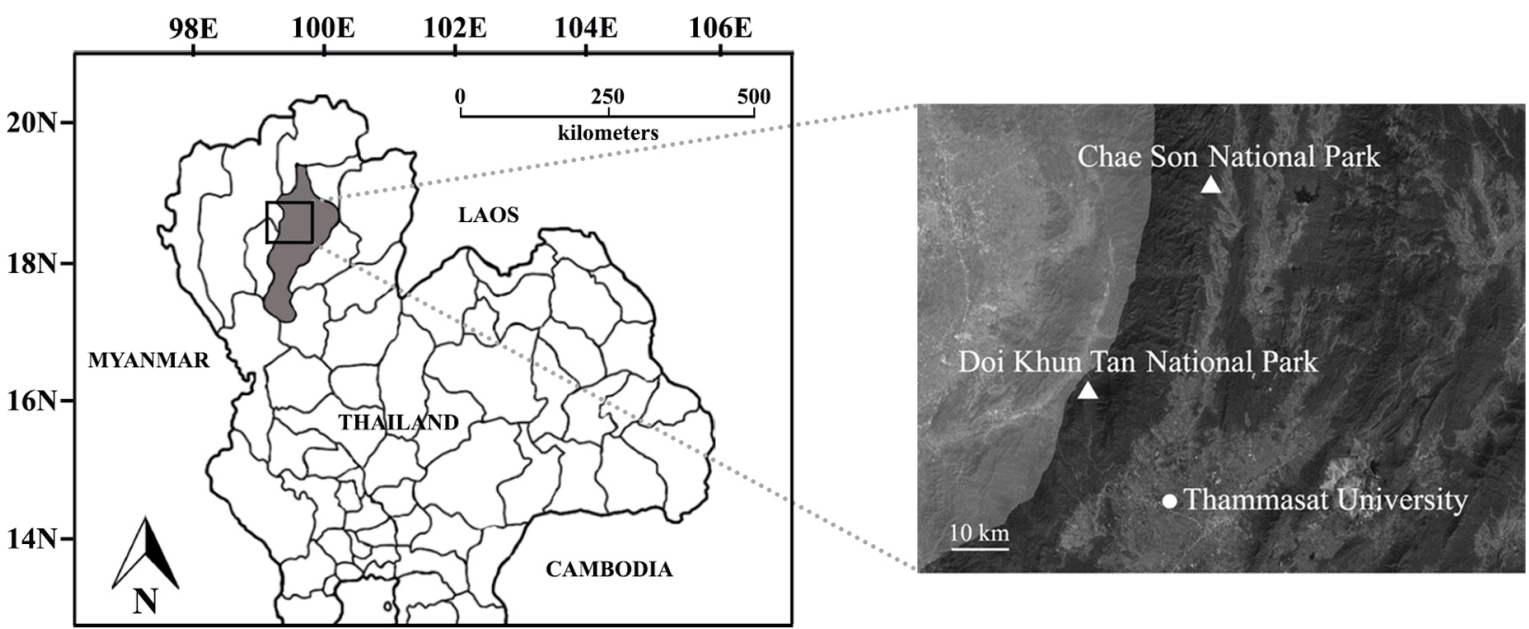

Fig. S1 Map showing the location of Thammasat University, Lampang Campus including Doi Khun Tan Natioanl Park and Chae Son National Park in Lampang Province, Northern Thailand.

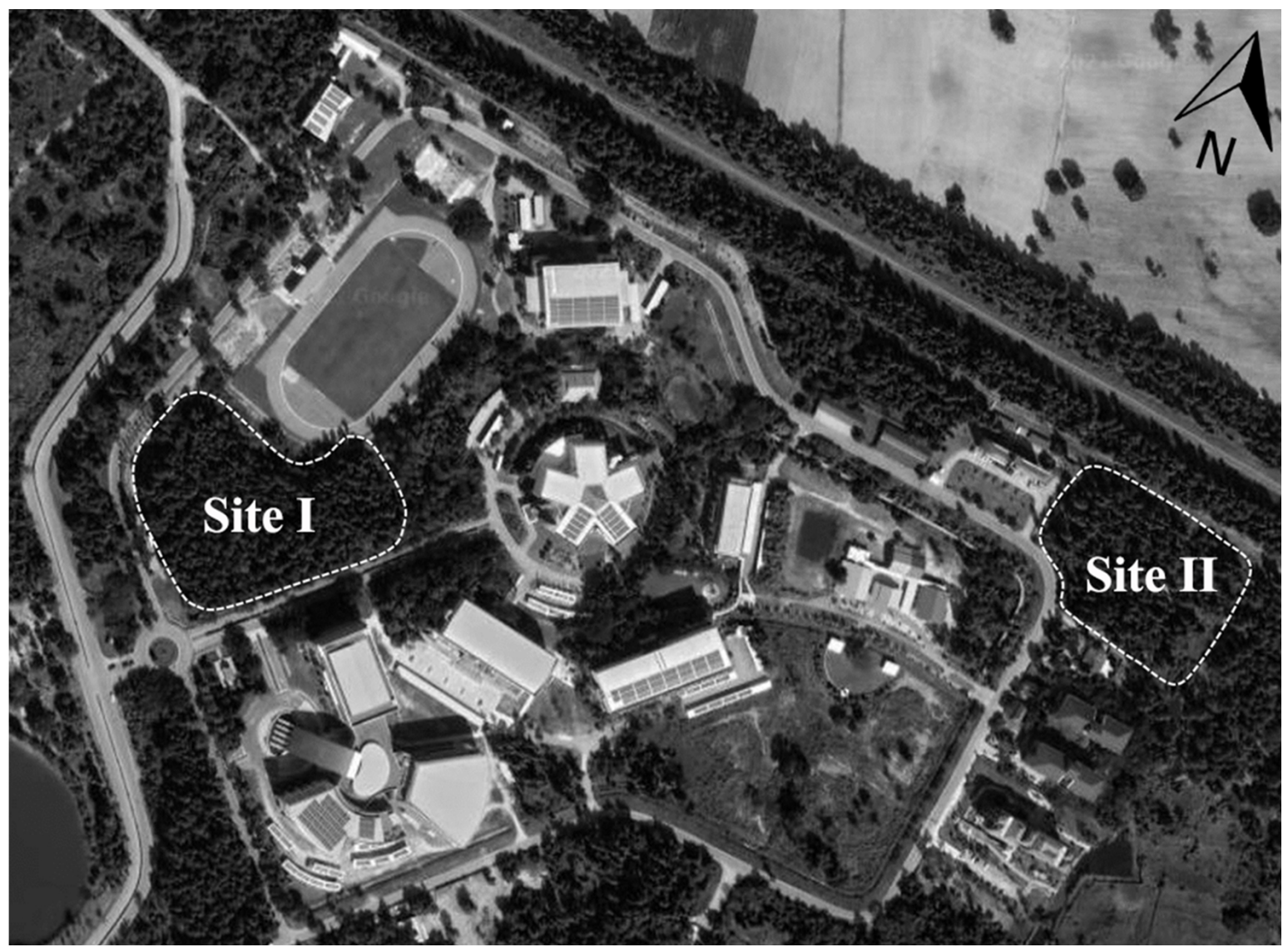

Fig. S2 Map showing the study site I and study site II of deciduous forest fragments at Thammasat University, Lampang Campus. 
Table S1 Species list of vascular plants occurring in lowland deciduous forest fragments at Thammasat University, Lampang Campus, Lampang Province, Northern Thailand.

\begin{tabular}{|c|c|c|c|c|c|}
\hline \multirow{2}{*}{ Family } & \multirow{2}{*}{ Scientific name } & \multirow{2}{*}{ Habit $^{1}$} & \multicolumn{3}{|c|}{ Study site ${ }^{2}$} \\
\hline & & & $\mathrm{I}$ & II & I \& II \\
\hline \multirow[t]{3}{*}{ Acanthaceae } & Andrographis paniculata (Burm.f.) Wall. ex Nees & $\mathrm{H}$ & 1 & 0 & \\
\hline & Asystasia gangetica (L.) T. Anderson & $\mathrm{H}$ & 2 & 1 & $\mathrm{X}$ \\
\hline & Thunbergia fragrans Roxb. & $\mathrm{C}$ & 1 & 0 & \\
\hline Anacardiaceae & Anacardium occidentale L. & ExT & 0 & 3 & \\
\hline Annonaceae & Ellipeiopsis cherrevensis (Pierre ex Finet \& Gagnep.) R.E. Fr. & US & 1 & 2 & $\mathrm{X}$ \\
\hline \multirow[t]{6}{*}{ Apocynaceae } & Holarrhena pubescens Wall. ex G. Don & $\mathrm{S}$ & 0 & 1 & \\
\hline & Hoya kerrii Craib & $\mathrm{C}$ & 1 & 0 & \\
\hline & Ichnocarpus frutescens (L.) W.T. Aiton & $\mathrm{C}$ & 2 & 1 & $\mathrm{X}$ \\
\hline & Streptocaulon juventas (Lour.) Merr. & $\mathrm{C}$ & 0 & 3 & \\
\hline & Telosma pallida (Roxb.) Craib & $\mathrm{C}$ & 1 & 0 & \\
\hline & Toxocarpus villosus (Blume) Decne. & $\mathrm{C}$ & 2 & 0 & \\
\hline Aristolochiaceae & Aristolochia tagala Cham. & $\mathrm{C}$ & 1 & 1 & $\mathrm{X}$ \\
\hline \multirow[t]{5}{*}{ Asteraceae } & Bidens pilosa $\mathrm{L}$. & $\mathrm{ExH}$ & 2 & 0 & \\
\hline & Chromolaena odorata (L.) R.M. King \& H. Rob. & $\mathrm{ExH}$ & 2 & 1 & $\mathrm{X}$ \\
\hline & Mikania micrantha Kunth & $\mathrm{C}$ & 3 & 3 & $\mathrm{X}$ \\
\hline & Praxelis clematidea (Griseb.) R.M. King \& H. Rob. & $\mathrm{ExH}$ & 2 & 2 & $\mathrm{X}$ \\
\hline & Tridax procumbens $\mathrm{L}$. & $\mathrm{ExH}$ & 2 & 0 & \\
\hline \multirow[t]{2}{*}{ Capparaceae } & Capparis sepiaria L. & $\mathrm{C}$ & 0 & 1 & \\
\hline & C. zeylanica L. & $\mathrm{C}$ & 0 & 1 & \\
\hline Chrysobalanaceae & Parinari anamensis Hance & $\mathrm{T}$ & 2 & 1 & $\mathrm{X}$ \\
\hline Cleomaceae & Cleome rutidosperma DC. & $\mathrm{H}$ & 0 & 1 & \\
\hline \multirow[t]{2}{*}{ Clusiaceae } & Garcinia nigrolineata Planch. ex T. Anderson & $\mathrm{T}$ & 4 & 0 & \\
\hline & Mammea siamensis (Miq.) T. Anderson & $\mathrm{T}$ & 1 & 0 & \\
\hline \multirow[t]{3}{*}{ Commelinaceae } & Commelina benghalensis $\mathrm{L}$. & $\mathrm{H}$ & 1 & 0 & \\
\hline & Murdannia gigantea (Vahl) G. Brückn. & $\mathrm{H}$ & 0 & 2 & \\
\hline & M. nudiflora (L.) Brenan & $\mathrm{H}$ & 1 & 0 & \\
\hline Connaraceae & Ellipanthus tomentosus Kurz & $\mathrm{T}$ & 0 & 1 & \\
\hline \multirow[t]{6}{*}{ Convolvulaceae } & Evolvulus alsinoides var. decumbens (R.Br.) Ooststr. & $\mathrm{H}$ & 1 & 0 & \\
\hline & E. nummularius (L.) L. & $\mathrm{H}$ & 1 & 0 & \\
\hline & Ipomoea obscura (L.) Ker Gawl. & $\mathrm{C}$ & 1 & 0 & \\
\hline & I. pes-tigridis $\mathrm{L}$. & $\mathrm{C}$ & 2 & 0 & \\
\hline & Merremia hirta (L.) Merr. & $\mathrm{H}$ & 1 & 0 & \\
\hline & M. vitifolia (Burm.f.) Hallier f. & $\mathrm{C}$ & 0 & 1 & \\
\hline Cucurbitaceae & Solena heterophylla Lour. & $\mathrm{C}$ & 0 & 1 & \\
\hline \multirow[t]{2}{*}{ Dilleniaceae } & Dillenia aurea Sm. & $\mathrm{T}$ & 1 & 2 & $\mathrm{X}$ \\
\hline & D. obovata (Blume) Hoogland & $\mathrm{T}$ & 1 & 2 & $\mathrm{X}$ \\
\hline Dipterocarpaceae & Dipterocarpus obtusifolius Teijsm. ex Miq. & $\mathrm{T}$ & 4 & 4 & $\mathrm{X}$ \\
\hline & D. tuberculatus Roxb. & $\mathrm{T}$ & 2 & 4 & $\mathrm{X}$ \\
\hline Ebenaceae & Diospyros ehretioides Wall. ex G. Don & $\mathrm{T}$ & 2 & 3 & $\mathrm{X}$ \\
\hline Erythroxylaceae & Erythroxylum cuneatum (Miq.) Kurz & $\mathrm{S}$ & 0 & 1 & \\
\hline Euphorbiaceae & Euphorbia heterophylla L. & ExH & 1 & 0 & \\
\hline & E. hirta L. & $\mathrm{H}$ & 1 & 1 & $\mathrm{X}$ \\
\hline Fabaceae & Aeschynomene americana $\mathrm{L}$. & ExUS & 1 & 0 & \\
\hline & Alysicarpus vaginalis (L.) DC. & $\mathrm{H}$ & 2 & 0 & \\
\hline & Caesalpinia furfuracea (Prain) Hattink & $\mathrm{C}$ & 1 & 0 & \\
\hline & Calopogonium mucunoides Desv. & $\mathrm{C}$ & 0 & 1 & \\
\hline & Centrosema pubescens Benth. & ExC & 3 & 1 & $\mathrm{X}$ \\
\hline & Chamaecrista pumila (Lam.) K. Larsen & $\mathrm{H}$ & 1 & 0 & \\
\hline & Clitoria macrophylla Wall. ex Benth. & $\mathrm{HC}$ & 1 & 0 & \\
\hline & Crotalaria alata Buch.-Ham. ex D. Don & US & 1 & 0 & \\
\hline & C. incana L. & $\mathrm{ExH}$ & 1 & 1 & $\mathrm{X}$ \\
\hline & Desmodium triflorum (L.) DC. & $\mathrm{H}$ & 1 & 0 & \\
\hline & D. velutinum (Willd.) DC. subsp. velutinum & US & 2 & 1 & $\mathrm{X}$ \\
\hline & Dunbaria punctata (Wight \& Arn.) Benth. & $\mathrm{C}$ & 1 & 1 & $\mathrm{X}$ \\
\hline & Flemingia stricta Roxb. ex W.T. Aiton & S & 2 & 3 & $\mathrm{X}$ \\
\hline & Indigofera cassioides Rottler ex DC. & S & 2 & 0 & \\
\hline & I. hirsuta L. & US & 2 & 0 & \\
\hline & Mimosa diplotricha C. Wright ex. Sauvalle & $\mathrm{ExH}$ & 2 & 1 & $\mathrm{X}$ \\
\hline & M. pudica L. & $\mathrm{ExH}$ & 1 & 0 & \\
\hline & Phyllodium pulchellum (L.) Desv. & $\mathrm{S}$ & 1 & 1 & $\mathrm{X}$ \\
\hline & Pueraria phaseoloides (Roxb.) Benth. & $\mathrm{C}$ & 1 & 0 & \\
\hline & Senna hirsuta (L.) H.S. Irwin \& Barneby & ExUS & 1 & 0 & \\
\hline & Sindora siamensis Teijsm. ex Miq. var. siamensis & $\mathrm{T}$ & 1 & 0 & \\
\hline & Stylosanthes humilis Humb., Bonpl. \& Kunth & $\mathrm{ExH}$ & 1 & 2 & $\mathrm{X}$ \\
\hline & Tephrosia vestita Vogel & US & 1 & 2 & $\mathrm{X}$ \\
\hline & Zornia gibbosa Span. & $\mathrm{H}$ & 1 & 0 & \\
\hline
\end{tabular}




\begin{tabular}{|c|c|c|c|c|c|}
\hline \multirow{2}{*}{ Family } & \multirow{2}{*}{ Scientific name } & \multirow{2}{*}{ Habit $^{1}$} & \multicolumn{3}{|c|}{ Study site $^{2}$} \\
\hline & & & $\mathrm{I}$ & II & I \& II \\
\hline \multirow[t]{2}{*}{ Hypericaceae } & Cratoxylum cochinchinense (Lour.) Blume & $\mathrm{T}$ & 3 & 3 & $\mathrm{X}$ \\
\hline & $\begin{array}{l}\text { C. formosum (Jacq.) Benth. \& Hook.f. ex Dyer subsp. } \\
\text { pruniflorum (Kurz) Gogelein }\end{array}$ & $\mathrm{T}$ & 2 & 2 & $\mathrm{X}$ \\
\hline \multirow[t]{5}{*}{ Lamiaceae } & Hyptis brevipes Poit. & $\mathrm{S}$ & 1 & 0 & \\
\hline & H. suaveolens (L.) Poit. & $\mathrm{S}$ & 2 & 2 & $\mathrm{X}$ \\
\hline & Leucas aspera (Willd.) Link & $\mathrm{H}$ & 1 & 0 & \\
\hline & L. decemdentata (Willd.) Sm. & $\mathrm{H}$ & 0 & 1 & \\
\hline & Rotheca serrata (L.) Steane \& Mabb. & $\mathrm{S}$ & 1 & 1 & $\mathrm{X}$ \\
\hline \multirow[t]{2}{*}{ Linderniaceae } & Lindernia ciliata (Colsm.) Pennell & $\mathrm{H}$ & 1 & 0 & \\
\hline & L. crustacea (L.) F. Muell. var. crustacea & $\mathrm{H}$ & 1 & 0 & \\
\hline Loganiaceae & Strychnos nux-blanda A.W. Hill & $\mathrm{T}$ & 2 & 1 & $\mathrm{X}$ \\
\hline \multirow[t]{8}{*}{ Malvaceae } & Sida acuta Burm.f. & US & 1 & 0 & \\
\hline & S. cordata (Burm.f.) Borss. Waalk. & US & 1 & 0 & \\
\hline & S. cordifolia L. & US & 2 & 2 & $\mathrm{X}$ \\
\hline & S. rhombifolia L. & $\mathrm{H}$ & 1 & 0 & \\
\hline & Triumfetta pilosa Roth & $\mathrm{H}$ & 2 & 2 & $\mathrm{X}$ \\
\hline & Urena lobata L. & US & 1 & 0 & \\
\hline & U. rigida Wall. ex. Mast. & US & 1 & 2 & $\mathrm{X}$ \\
\hline & Waltheria indica $\mathrm{L}$. & US & 1 & 0 & $\alpha$ \\
\hline Melastomataceae & Memecylon scutellatum (Lour.) Hook. \& Arn. var. scutellatum & $\mathrm{S}$ & 2 & 3 & $\mathrm{X}$ \\
\hline Ochnaceae & Ochna integerrima (Lour.) Merr. & $\mathrm{S}$ & 2 & 3 & $\mathrm{X}$ \\
\hline Olacaceae & Olax psittacorum (Lam.) Vahl & $\mathrm{C}$ & 0 & 1 & \\
\hline Oleaceae & Jasminum elongatum (P.J. Bergius) Willd. & ScanS & 1 & 0 & \\
\hline Onagraceae & Ludwigia hyssopifolia (G. Don) Exell & $\mathrm{H}$ & 2 & 0 & \\
\hline Orchidaceae & Geodorum recurvum (Roxb.) Alston & TerO & 0 & 1 & \\
\hline Oxalidaceae & Biophytum umbraculum Welw. & $\mathrm{H}$ & 0 & 2 & \\
\hline Passifloraceae & Passiflora foetida $\mathrm{L}$. & $\mathrm{ExC}$ & 0 & 1 & \\
\hline \multirow[t]{3}{*}{ Phyllanthaceae } & Antidesma ghaesembilla Gaertn. & $S$ & 1 & 0 & \\
\hline & Phyllanthus urinaria $\mathrm{L}$. & $\mathrm{H}$ & 1 & 0 & \\
\hline & P. virgatus G. Forst. & $\mathrm{H}$ & 2 & 0 & \\
\hline Polygalaceae & Polygala elongata Klein ex Willd. & $\mathrm{H}$ & 2 & 1 & $\mathrm{X}$ \\
\hline \multirow{2}{*}{ Rhamnaceae } & Ventilago denticulata Willd. & $\mathrm{C}$ & 0 & 1 & \\
\hline & Ziziphus oenoplia (L.) Mill. var. oenoplia & $\mathrm{C}$ & 1 & 0 & \\
\hline \multirow[t]{4}{*}{ Rubiaceae } & Catunaregam spathulifolia Tirveng. & $\mathrm{T}$ & 1 & 0 & \\
\hline & Paederia pilifera Hook.f. & $\mathrm{C}$ & 1 & 0 & \\
\hline & Spermacoce ocymoides Burm.f. & ExH & 1 & 0 & \\
\hline & Vangueria pubescens Kurz & US & 0 & 1 & \\
\hline \multirow[t]{2}{*}{ Rutaceae } & Clausena excavata Burm.f. & $\mathrm{S}$ & 1 & 1 & $\mathrm{X}$ \\
\hline & Harrisonia perforata (Blanco) Merr. & ScanS & 1 & 0 & \\
\hline Salicaceae & Casearia grewiifolia Vent. & $\mathrm{T}$ & 0 & 2 & \\
\hline \multirow[t]{2}{*}{ Simaroubaceae } & Brucea javanica (L.) Merr. & $\mathrm{S}$ & 2 & 2 & $\mathrm{X}$ \\
\hline & Eurycoma longifolia Jack & $\mathrm{S}$ & 1 & 3 & $\mathrm{X}$ \\
\hline Smilacaceae & Smilax luzonensis C. Presl & $\mathrm{C}$ & 0 & 1 & \\
\hline Verbenaceae & Lantana camara L. & $\mathrm{ExC}$ & 2 & 0 & \\
\hline Vitaceae & Leea indica (Burm.f.) Merr. & $\mathrm{S}$ & 1 & 1 & $X$ \\
\hline
\end{tabular}

${ }^{1}$ Habit: $\mathrm{T}=$ Tree, $\mathrm{S}=$ Shrub, ScanS = Scandent shrub, US = Undershrub, $\mathrm{H}=$ Herbaceous plant, $\mathrm{HC}=$ Herbaceous climber, $\mathrm{C}=$ Climber, TerO $=$ Terrestrial orchid, and Ex $=$ Exotic plant.

${ }^{2}$ The abundance of each species in each study site: $5=$ most abundant (76-100\%), $4=$ more abundant $(51-75 \%), 3=$ common $(26-50 \%), 2=$ few $(6-25 \%), 1=$ rare $(1-5 \%), 0=$ absent. 